\begin{tabular}{||l|l|l||}
\hline \multicolumn{2}{|c|}{ PublisherInfo } \\
\hline \hline PublisherName & $:$ & BioMed Central \\
\hline \hline PublisherLocation & $:$ & London \\
\hline \hline PublisherImprintName & $:$ & BioMed Central \\
\hline \hline
\end{tabular}

130591474-760XGenome BiologyGenome BiolLife SciencesAnimal Genetics and GenomicsHuman GeneticsPlant Genetics \& GenomicsMicrobial Genetics and GenomicsBioinformaticsEvolutionary BiologyBiomedical and Life Sciences221211343

CoverDate : 2001-12-

The Author(s)2001

\title{
The genome has landed - let the debate begin
}

\begin{tabular}{||l|l|l||}
\hline \multicolumn{2}{|c|}{ ArticleInfo } \\
\hline \hline ArticleID & $:$ & 3976 \\
\hline \hline ArticleDOI & $:$ & $10.1186 /$ gb-spotlight-20010212-01 \\
\hline \hline ArticleCitationID & $:$ & spotlight-20010212-01 \\
\hline \hline ArticleSequenceNumber & $:$ & 47 \\
\hline \hline ArticleCategory & $:$ & Research news \\
\hline \hline ArticleFirstPage & $:$ & 1 \\
\hline \hline ArticleLastPage & $:$ & 2 \\
\hline \hline & & RegistrationDate : 2001-02-12 \\
\hline ArticleHistory & $:$ & OnlineDate \\
\hline \hline ArticleCopyright & $:$ & BioMed Central Ltd2001 $02-12$ \\
\hline \hline ArticleGrants & $:$ & \\
\hline \hline ArticleContext & $:$ & 130592211 \\
\hline \hline
\end{tabular}


LONDON Sequencing the human genome has been likened to landing on the moon. Two decades ago most people laughed at the prospect. One decade ago the task looked achievable but would be unbelievably slow. Then, a couple of years back we had some $5 \%$ of the code and the first draft.

In 1998, when Craig Venter set up his own research unit and privatised the sequencing program, he fired a starting pistol. While private investors poured money into Venter's Celera Genomics, governments and the Wellcome Trust were forced to divert streams of cash into the race. The publicly funded Human Genome Project (HGP) was eager to publish a sequence of the genome, and quash any attempt to gain ownership of the information via patenting.

The result has been two-fold, says Denis Alexander, head of the Molecular Immunology Programme at the Babraham Institute outside Cambridge, UK. First, having two separate efforts has undeniably accelerated the pace of research, knocking a couple of years off the anticipated time-scale. But second, he like many believes that the high-profile scrap has probably damaged public confidence or public perceptions of science. "You can imagine that when the public hears about scientists fighting about things they get more negative about science," says Alexander. "If you want conspiracy theories then here is a perfect example - a company selling your genetic data for money."

Those involved in genetics are well aware that the field has a poor track record at wooing public opinion. The announcement of the draft human genome sequence in summer 2000 was a carefully orchestrated photo-opportunity for the opponents to stand side-by-side, literally, and give the impression of the amicable face of science - painting the picture that genetic technology is safe in their hands.

Now, with their simultaneous publications of the data - Celera in Science and the HGP in Nature - the two camps once again seem to be showing signs of co-operation.

"We don't consider the events of the past two years to have been a 'race' between the two sequencing efforts," says Mark Guyer, assistant director for scientific co-ordination at the National Human Genome Research Institute (NHGRI), Bethesda, Maryland. "The fact that the International Human Genome Sequencing Consortium [the HGP] submitted new sequencing data on a daily basis into the public nucleotide sequencing databases obviated any resemblance of the situation to a 'competition'. Much more to the point is that the two efforts, in parallel, were each a race against ignorance and disease, to provide as rapidly as possible new vital information which the larger scientific research community can use to speed the development of diagnostic, therapeutic and preventative strategies against human illness."

That was said in the week running up to today's official announcement of the publications. It was a week of unprecedented secrecy in the publishing community, with Nature and Science both making prepublication manuscripts available to selected journalists via password-protected web sites. But even with strongly worded threats against breaking the Monday 12 February embargo, publication of stories over the preceding weekend caused that embargo to collapse on Sunday afternoon. 
If the scientists weren't involved in a race, what happened next looked more like a minor war. Celera opened up by claiming that theirs is a more complete sequence, and Craig Venter accused the consortium of having wasted public money on the project and produced uneven results.

At a packed London press conference today, Sir John Sulston, who headed the Sanger Centre in Cambridge, UK, during the sequencing effort, fired back with a stinging reply. "I have unfortunately to comment about Celera's product - it would be much better not to, but the last part of their paper is devoted to comparing their product with an out-of-date product of ours."

He then set about exposing failures in Celera's methods, which left them dependent on the public databases in order to complete their sequence. Celera had initially claimed that their use of shot-gun sequencing would be sufficient to assemble the genome. "In the paper they do not show any attempts at that assembly," commented Sulston. "It is very clear that the assembly did not succeed anything like as well as they hoped. The coverage and the gaps were far inferior to what Celera hoped in their business plan." He also said that as far as anyone could see, it had few if any advantages over the publicly accessible databases.

Martin Bobrow, Head of the Department of Medical Genetics at the University of Cambridge also added that the quality of a database is not just determined by its size, and contents, but by its utility. He believes that the uncertainties surrounding the restrictions on access and subsequent use of data from Celera's database mean that what it contains is in reality of limited use.

Director of the Wellcome Trust, Michael Dexter also reiterated his anxiety about the genome being available on a 'pay-to-view basis', as if it were television entertainment.

Both parties, however, state that publication of the first analysis of the genome should fuel serious public discussion about how the data should be used to enhance human health. "There is an absolute and completely important need to engage the public in where we are before we get to the end [of the sequencing project]. We want the public to think about what is going to come out of this and make decisions before we have the full sequence. There will be things that society chooses not to have and avenues of development that we decide not to go down," comments Don Powell, press spokesman at the Sanger Centre.

Celera's paper talks of the need to educate people away from believing in simplistic views of genetic reductionism and determinism. The HGP publication concludes by drawing attention to the need to "involve society at large in the work ahead... To that end, serious attention must be paid to the many ethical, legal and social implications raised by the accelerated pace of genetic discovery."

It will be a debate in which it is difficult to spot the division between fact and fantasy. Speaking last week at the World Life Sciences Forum in Lyon, France, Francis Collins, director of the US National Human Genome Research Institute claimed that within the next 30 years scientists would be able to manipulate human genomes, bringing the real possibility of humanity starting to direct its own evolution, saying that he finds the prospect "interesting but somewhat chilling."

The human genome contains in the order of three billion characters of code, a vast amount of genetic text that is equivalent to 6,000 short novels. This mass of 'text' will probably be exceeded by the commentaries written about it. One thing, however, is likely to be the same between the genome and the appraisals - only about $1 \%$ seems to say anything useful. 
As the political dust settles researchers are also trying to decide quite what has been achieved. Some who have been given early access to the data were surprised by the lack of new insight they gained. "For problems that have been well studied and do not involve huge gene families, a whole genome sequence is unlikely to reveal lots of new genes," says Andrew Murray from Harvard University.

Others question how useful the genome will be in sorting out real problems. "The question is will genetics short cut us into a quicker understanding of fundamental physiology. Maybe it will, maybe it won't," says David Barker, head of the University of Southampton's Fetal Origins of Adult Disease Division, and famous for establishing a link between fetal nutrition and the development of coronary heart disease and diabetes in adults. Barker believes that there is a need to stop concentrating so much funding on genetics and to return to neglected disciplines such as whole animal physiology.

Still others, like Alexander, who are keen to use the full sequence, are also cautious about its potential: "Identifying the genes expressed, for example, in immune cells is only the very first step in understanding the molecular mechanisms underlying immune function. The immune system, like the central nervous system, provides a classic example of the need to investigate molecular function within the physiological context of the system as a whole. It comprises a complex interacting network of celltypes in constant communication with each other. That is why working on molecules in the test-tube, or even using cell lines, will never give the final answers on how the system works."

And many, including Professor Colin Cooper of the UK's Institute of Cancer Research based in Surrey, are ecstatic: "My life has changed practically beyond recognition over the last year. For every field of health the central question is how to use information from the human genome to help patients."

\section{References}

1. Celera Genomics, [http://www.celera.com/]

2. The Wellcome Trust, [http://www.wellcome.ac.uk/]

3. The Human Genome Project (Sanger Centre, UK), [http://www.sanger.ac.uk/HGP/]

4. The Human Genome Project (National Human Genome Research Project, USA), [http://www.nhgri.nih.gov/HGP/]

5. Science, [http://www.sciencemag.org/genome2001]

6. Nature - Genome Gateway, [http://www.nature.com/genomics/human/\#]

7. The Sanger Centre, [http://www.sanger.ac.uk]

8. National Centre for Biotechnology Information, [http://www.ncbi.nlm.nih.gov/]

9. 'Celera submits to Science - or is it the other way round?' BioMed central 14 December 2000, [http://www.the-scientist.com/news/20001214/05] 